\title{
PHYSICOCHEMICAL QUALITY CONTROL OF BEE HONEYS FROM CAMPOS GERAIS REGION OF PARANÁ - BRAZIL
}

\author{
DÉBORA MARIA BORSATO* \\ TAÍS VARGAS** \\ LAÍS KOOP***

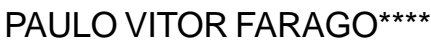 \\ MARECI MENDES DE ALMEIDA*****
}

\begin{abstract}
Bee (Apis mellifera L.) honeys have been widely used for therapeutic and nutritional proposes. For evaluating the honey production, physicochemical approaches have been extensively performed to ensure that this hive product is authentic in respect to the legal requirements. The aim of this paper was to discuss the quality control of 93 samples of honey from Campos Gerais region of Paraná State - South Brazil by physicochemical parameters. Moisture, reducing sugars, sucrose, water-insoluble solids, ash, free acidity, $\mathrm{pH}$, activity of diastase, hydroxymethylfurfural content and colour were performed by the standard usual methods. Samples were also classified in floral honeys or honeydew honeys according to the Kirkwood equation. A total of 71 samples (76.34\%) showed values in accordance with the Brazilian legal requirements for all the achieved physicochemical parameters. Otherwise, all the studied honeys were likewise within the legislation limits only for water-insoluble solids and colour. For $\mathrm{pH}$, an additional parameter that has not been provided in honey legislation, samples showed values ranging from 3.60 to 5.35 . By the Kirkwood equation, 61 honeys were considered as floral products.
\end{abstract}

KEY-WORDS: HONEY QUALITY; Apis mellifera L.; ACTIVITY OF DIASTASE; ADULTERATIONS IN HONEY.

* Doutoranda em Ciências Farmacêuticas, Programa de Pós-graduação em Ciências Farmacêuticas, Universidade Federal do Paraná (UFPR), Curitiba, PR (e-mail: dmborsato@yahoo.com.br).

** Mestre em Ciência e Tecnologia de Alimentos, Programa de Pós-graduação em Ciência e Tecnologia de Alimentos, Universidade Estadual de Ponta Grossa (UEPG), Ponta Grossa, PR (e-mail: taisvargas@pop.com.br).

*** Graduanda em Engenharia de Alimentos, Departamento de Engenharia de Alimentos, UEPG, Ponta Grossa, PR (e-mail: lais_koop@yahoo.com.br).

**** Doutor em Química, Professor Adjunto, Departamento de Ciências Farmacêuticas, UEPG, Ponta Grossa, PR (e-mail: pvfarago@uepg.br).

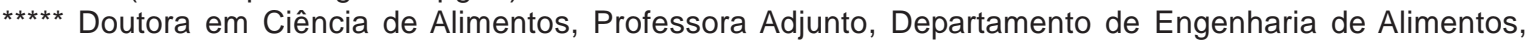
UEPG, Ponta Grossa, PR (e-mail: mareci@uepg.br). 


\section{INTRODUCTION}

The medicinal properties of honey and other hive products have been remarkable reported for a number of therapeutic and nutritional proposes as revised by Meda et al. (2004). Antibacterial activity against a wide range of potential human pathogens as Enterobacter aerogenes, Escherichia coli and Staphylococcus aureus have been archived (LUSBY, COOMBES \& WILKINSON, 2005). Increasing interest has been recently accorded to the use of honeys for management of wounds due to their antimicrobial potential against microorganisms isolated from skin lesions (BASUALDO et al., 2007). Emsen (2007) has been showed the use of sterilized honey for split thickness skin graft fixation. No complications such as graft loss, infection and graft rejection were the beneficial effects observed in the evaluated patients.

In despite of these medicinal and nutritional uses, some problems have been verified in honey production as diversity of sources, inadequate processing and adulterations. The major concern about honey quality is to ensure that honey is authentic in respect to the legislative requirements (BOGDANOV \& GALLMANN, 2008). Physicochemical approaches have been extensively used (MALACALZA et al., 2007; MARCHINI, MORETI \& OTSUK, 2005; PADOVAN et al., 2008; SODRÉ et al., 2007) for the quality evaluation of honeys due to their easy-handing and low cost features.

Although many studies into physicochemical and enzymatic constituents of honeys are available, further investigations are required in particular regions like South Brazil where such data are lacking. Therefore the goal of this paper was to discuss the quality control of bee (Apis mellifera L.) honeys from Campos Gerais region of Brazil by physicochemical parameters.

\section{EXPERIMENTAL}

\subsection{MATERIAL}

Ninety-three samples of bee ( $A$. mellifera) honey were kindly provided by beekeepers from Campos Gerais region in Paraná state of South Brazil. Honey samples were collected from 2004 to 2007 , and immediately cooled at $4 \pm 2^{\circ} \mathrm{C}$ for the further physicochemical assays.

\subsection{PHYSICOCHEMICALANALYSES}

As summarized in Table 1, moisture, reducing sugars, sucrose, water-insoluble solids, ash, free acidity, $\mathrm{pH}$, activity of diastase, hydroxymethylfurfural (HMF) content and colour were performed in triplicate for the honey samples according to the current standard methods proposed by the literature (AOAC, 1997; BIANCHI, 1981; KOMATSU, 1996; SANTOS, MALASPINA\& PALMA, 2003; VARGAS, 2006).

\section{TABLE 1 - PHYSICOCHEMICAL ANALYSES PERFORMED IN 93 SAMPLES OF BEE (Apis mellifera L.) HONEY FROM CAMPOS GERAIS REGION OF BRAZIL}

\begin{tabular}{lll}
\hline Physicochemical analyses & Method & Reference \\
\hline moisture & refractometry & AOAC, 2000 \\
reducing sugars & Lane-Eynon titration & BOGDANOV, MARTIN \& LÜLLMANN, 1997 \\
sucrose & Lane-Eynon titration & BOGDANOV, MARTIN \& LÜLLMANN, 1997 \\
water-insoluble solids & gravimetry & BOGDANOV, MARTIN \& LÜLLMANN, 1997 \\
ash & gravimetry & VARGAS, 2006 \\
free acidity & direct titration & BOGDANOV, MARTIN \& LÜLLMANN, 1997; \\
& & KOMATSU, 1996 \\
pH & potentiometry & BOGDANOV, MARTIN \& LÜLLMANN, 1997; \\
& & KOMATSU, 1996 \\
activity of diastase & Spectrophotometry & SANTOS, MALASPINA \& PALMA, 2003 \\
hydroxymethylfurfural content & spectrophotometry & AOAC, 2000 \\
colour & spectrophotometry & BIANCHI, 1981 \\
\hline
\end{tabular}


Concerning the Kirkwood equation (KIRKWOOD, MITCHELL \& SMITH, 1960, 1961), samples were discriminated in floral honeys or honeydew honeys by the index resulted from the relationship among $\mathrm{pH}$, ash and reducing sugars. If applicable, values of mean and standard deviation (SD) were calculated for the achieved experimental data.

\section{RESULTS AND DISCUSSION}

Table 2 and Figure 1 indicate the obtained results for the physicochemical analyses of bee (A. mellifera) honeys from Campos Gerais region of Brazil as mean, standard deviation (SD) and range. TABLE 2 - PHYSICOCHEMICAL RESULTS FOR 93 SAMPLES OF BEE (Apis mellifera L.)
HONEY FROM CAMPOS GERAIS REGION OF BRAZIL

\begin{tabular}{|c|c|c|c|c|c|}
\hline \multirow[b]{2}{*}{ Physicochemical parameters } & \multicolumn{2}{|c|}{ Reference values * } & \multirow[b]{2}{*}{ Mean } & \multirow[b]{2}{*}{ SD } & \multirow[b]{2}{*}{ Range } \\
\hline & $\begin{array}{l}\text { Floral } \\
\text { honey }\end{array}$ & $\begin{array}{l}\text { Honeydew } \\
\text { honey }\end{array}$ & & & \\
\hline moisture (\%) & $\leq 20$ & $\leq 20$ & 18.26 & 1.32 & $15.10-21.58$ \\
\hline reducing sugars (\%) & $\geq 65$ & $\geq 60$ & 70.18 & 5.34 & $58.75-82.37$ \\
\hline sucrose (\%) & $\leq 6$ & $\leq 15$ & 3.71 & 2.99 & n.d. -14.7 \\
\hline water-insoluble solids (\%) ** & $\leq 0.1$ & $\leq 0.1$ & 0.04 & 0.04 & n.d. -0.22 \\
\hline ash (\%) & $\leq 0.6$ & $\leq 1.2$ & 0.36 & 0.30 & n.d. -1.68 \\
\hline $\operatorname{acidity}\left(\mathrm{mEq} \mathrm{kg}{ }^{-1}\right)$ & $\leq 50$ & $\leq 50$ & 27.37 & 10.49 & $8.75-62.71$ \\
\hline $\mathrm{pH}$ & n.e. & n.e. & 4.32 & 0.36 & $3.60-5.35$ \\
\hline activity of diastase (Göthe) & $\geq 8$ & $\geq 8$ & 15.50 & 9.23 & $1.19-47.14$ \\
\hline hydroxymethylfurfural $\left(\mathrm{mg} \mathrm{kg}^{-1}\right)$ & $\leq 60$ & $\leq 60$ & 10.98 & 14.83 & n.d. -83.83 \\
\hline colour (mm Pfund) & $\begin{array}{l}\text { water- } \\
\text { white to } \\
\text { dark- } \\
\text { amber }\end{array}$ & $\begin{array}{l}\text { water-white } \\
\text { to dark- } \\
\text { amber }\end{array}$ & $\begin{array}{l}\text { light } \\
\text { amber } \\
(64.73)\end{array}$ & n.a. & $\begin{array}{c}\text { water-white to } \\
\text { dark amber } \\
(-7.13-155.54)\end{array}$ \\
\hline
\end{tabular}

* according to the Brazilian requirements (BRASIL, 2000).

** for 80 samples of bee (A. mellifera) honey.

$\star \star \star$ if $\mathrm{HMF}<15 \mathrm{mg} \mathrm{kg}^{-1}$, the official lower limit for diastase is $\geq 3$ Göthe.

n.a. = not applicable, n.d. = not detected, n.e. = not established.

The moisture content for the evaluated hive products showed a mean of $18.26 \%$ with a range from 15.10 to $21.58 \%$, respectively for the honeys designed as $h \# 92$ and $h \# 69$. A total of eight samples of bee (A. mellifera) honey ( $h \# 7, h \# 15, h \# 33, h \# 46, h \# 47, h \# 50, h \# 69$ and $h \# 73$ ) achieved moisture higher than $20 \%$ that correspond to $8.60 \%$ of the total sampling. The regulation (BRASIL, 2000) sets values equal or lower to $20 \%$ for the moisture of bee honeys due to the tropical conditions founded in Brazil that can improve some fermentation processes, e.g. high humidity and high temperature. This limit is also recognized by Mercosul (1999) and Codex Alimentarius Commission (2001) from World Health Organization. However, the European Honey Commission (BOGDANOV, MARTIN \& LÜLLMANN, 1997) admits moisture contents up to $21 \%$. The observed higher water contents in bee honeys can be resulted from one or more particular features as botanical origin, inappropriate processing, unsuitable 
packaging, adulterations and climatic conditions, e.g. rainy seasons (RODRÍGUEZ, et al., 2004; SILVA, QUEIROZ \& FIGUEIRÊDO, 2004).

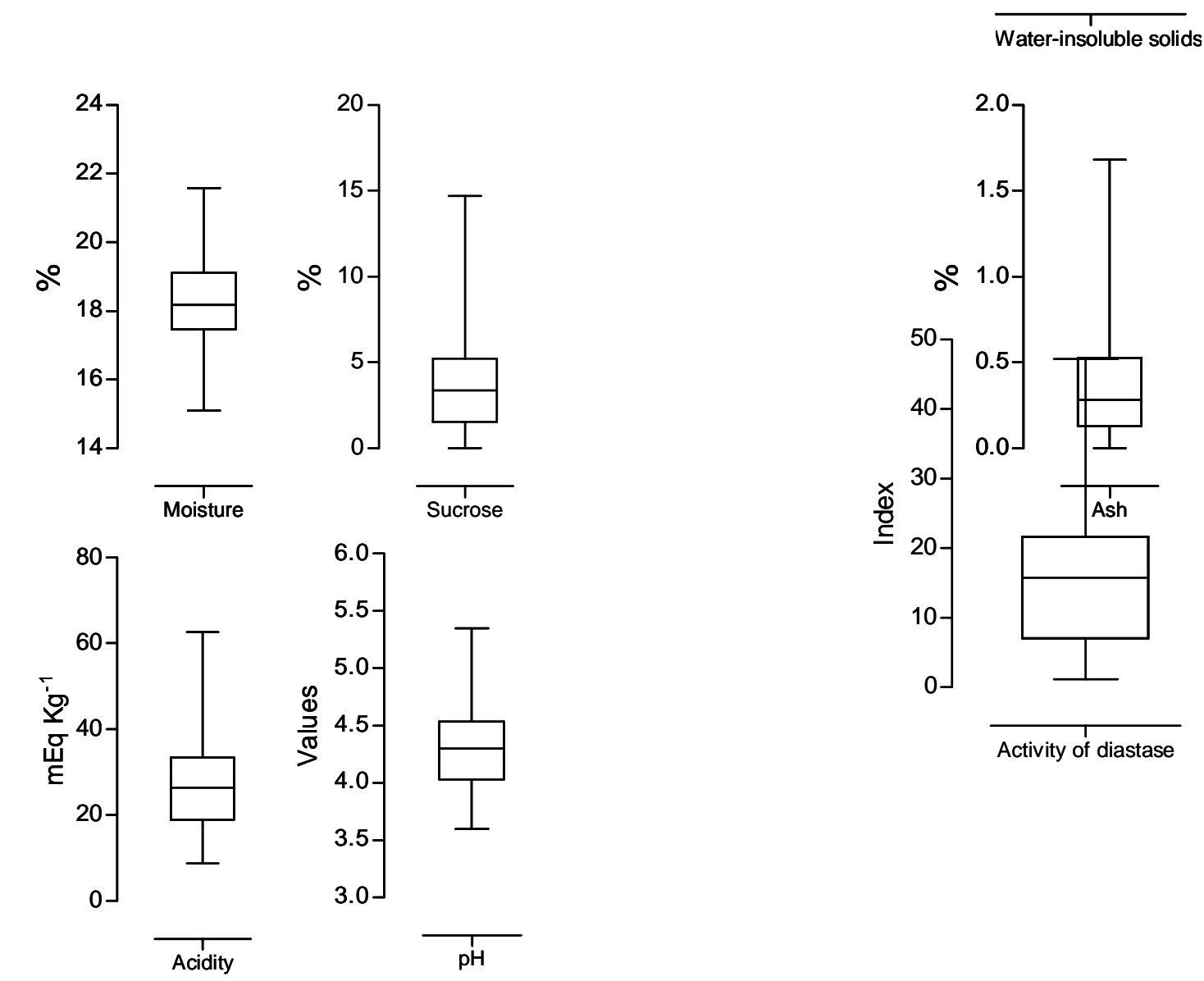

\section{FIGURE 1 - BOX-PLOT SHOWING PHYSICOCHEMICAL RESULTS FOR 93 SAMPLES OF BEE (Apis mellifera L.) HONEY FROM CAMPOS GERAIS REGION OF BRAZIL}

Values ranging from 58.75 to $82.37 \%$ were respectively verified for samples $h \# 7$ and $h \# 74$ in the Lane-Eynon method for reducing sugars. In addition, a total of 75 honey samples (80.64\%) presented reducing sugars content higher than $65 \%$. For sucrose, a mean of $3.71 \%$ was obtained. Moreover, 77 studied honeys (82.79\%) achieved sucrose content lower than $6 \%$. Reducing sugars and sucrose can be both used as physicochemical approaches for identifying an early harvest of honey samples due to sucrose from nectar is not mainly converted to glucose and fructose (SODRÉ, MARCHINI \& CARVALHO, 2001). Furthermore, some adulterations as low nectar content in honeys or an intended addition of commercial sugar products, e.g. totally-inverted sucrose, partially-inverted sucrose, corn syrup or highfructose syrup, can be evaluated (SIVAKESAVA \& IRUDAYARAJ, 2001). However, activity of diastase and HMF content are further required for confirming these adulterations (VARGAS, 2006).

Regarding the recommended values for reducing sugars and sucrose by the Brazilian regulation (BRASIL, 2000), floral honeys and honeydew honeys show distinct limits. For honey with floral origin, a minimum of $65 \%$ and a maximum of $6 \%$ are archived as parameters for reducing sugars and sucrose, respectively. For honeydew honeys, these respective requirements can show limits of a minimum of $60 \%$ and a maximum of $15 / \%$. According to the obtained results, only sample $h \# 7$ showed a value lower (58.75\%) than a minimum set for the legal document (BRASIL, 2000) for reducing sugars. Also considering this legislation, six samples ( $h \# 24, h \# 32, h \# 45, h \# 46, h \# 47$ and $h \# 55$ ) achieved higher data for sucrose. Otherwise, the amount of sucrose was not observed in seven samples ( $h \# 41, h \# 48$, 
$\mathrm{h} \# 57, \mathrm{~h} \# 71, \mathrm{~h} \# 74, \mathrm{~h} \# 78$ and $\mathrm{h} \# 80$ ) by the proposed method. Sucrose content lower than $0.20 \%$ can be attributed to the enzymatic activity of invertase which performs a decrease of this non-reducing disaccharide amount during the storage (ANKLAM, 1998).

A mean of $0.04 \%$ was obtained for the water-insoluble solids, a parameter that represents suspended wax particles and/or insect and vegetables debris in honeys (MENDES et al., 1998). All samples of bee (A. mellifera) honey were likewise within the limit of $0.5 \%$ for pressed honeys and $0.1 \%$ for usual centrifugated commercial honeys as established by the Brazilian regulation (BRASIL, 2000).

The ash content varied from 0.01 to $1.68 \%$, respectively for samples $h \# 46$ and $h \# 11$. By the proposed method (VARGAS, 1996), ash was not analytically detected in one bee honey sample ( $h \# 88$ ). Due to ash can reveal the mineral content that indicates the nectar quality and some soil conditions where the botanical species grow (FELSNER et al., 2004; MARCHINI, MORETI \& OTSUK, 2005), the Brazilian requirements were set in the respective limits of $0.6 \%$ and $1.2 \%$ for floral honeys and honeydew honeys (BRASIL, 2000). Regarding the performed honey samples, only $\mathrm{h} \# 11$ and $\mathrm{h} \# 19$ showed higher values for ash.

For free acidity, the studied bee (A. mellifera) honeys from Campos Gerais region showed values ranging from 8.75 to $62.71 \mathrm{mEq} \mathrm{kg}^{-1}$. According to the legislation about control quality of honeys in Brasil (2000), samples $h \# 7$ (62.71 $\left.\mathrm{mEq} \mathrm{kg}^{-1}\right)$ and $h \# 20\left(53.30 \mathrm{mEq} \mathrm{kg}{ }^{-1}\right)$ exceeded the permitted limit of $50 \mathrm{mEq} \mathrm{kg}^{-1}$ for this physicochemical parameter. A higher value for free acidity can be resulted from the addition of sucrose syrup or modified starch by acid hydrolysis or can indicate a fermentation process, especially when moisture is higher than 20\% (BRASIL, 2000; MEDA et al., 2005).

Analytical data for $\mathrm{pH}$ provided results from 3.60 to 5.35 , respectively for samples $\mathrm{h} \# 58$ and $\mathrm{h} \# 74$. Legal documents from national and international institutions have no reports about $\mathrm{pH}$ for bee honeys (BOGDANOV, MARTIN \& LÜLLMANN, 1997; BRASIL, 2000; MERCOSUL, 1999). According to Crane (1983), some changes in $\mathrm{pH}$ can be due to floristic composition and floral diversity of the region. Also a singular soil composition and taxa association can influence the final honey composition and $\mathrm{pH}$ (NORONHA, 1997).

A proportional behavior between free acidity and $\mathrm{pH}$ could not be documented because their values represent dissimilar features. Acidity is influenced by chemical properties of the organic and inorganic acids, e.g. tri-dimensional molecular structure and ionization rate, within honey samples likewise by the particular amino acids content provided by nectar and salivary enzymes of $A$. mellifera. In despite, $\mathrm{pH}$ represents a measure of the acidity of dissolved hydrogen ions $\left(\mathrm{H}^{+}\right)$in water from the honey samples.

Values ranging from 1.19 to 47.14 were achieved for samples $h \# 70$ and $h \# 38$ for diastase on the Göthe scale, respectively. Concerning the standards set by the Brazilian legislation (BRASIL, 2000), a minimum of 8 for diastase index is required on the Göthe scale. However, a minimum of 3 is also allowed for diastase if the HMF content is within the limit of $15 \mathrm{mg} \mathrm{kg}^{-1}$. Seven bee honeys ( $\mathrm{h} \# 5$, $\mathrm{h} \# 70, \mathrm{~h} \# 84, \mathrm{~h} \# 85, \mathrm{~h} \# 88, \mathrm{~h} \# 92$ and $\mathrm{h} \# 93$ ) showed diastase index lower than 3 . From the 14 studied samples that archived values between 3 and 8, two samples ( $h \# 45$ and $h \# 55$ ) archived HMF content higher than $15 \mathrm{mg} \mathrm{kg}^{-1}$. Diastase is a thermolabile $\alpha$-amylase responsible for splitting starch chains into dextrins and maltose (WHITE, 1975). Diastase was initially used as a possible means of distinguishing between natural and artificial honeys. However, diastase is also widely recognized as a parameter for the evaluation of honey freshness, because its activity decreases in old or heated honeys (BOGDANOV, MARTIN \& LÜLLMANN, 1997; TOSI et al., 2008; WHITE, 1975). Commercial syrups obtained from totally or partially-inverted sucrose by acid hydrolysis and heating of sugar cane can reduce the diastase value of honeys (NORONHA, 1997). High-fructose syrups prepared from corn starch by enzymatic activities of amylases and isomerases show diastase in normal range, but reveal high HMF content (VARGAS, 2006). Some of these changes can be related with the verified results for the nine honeys samples that exceeded the reported limits.

HMF content varied from 0.30 to $83.83 \mathrm{mg} \mathrm{kg}^{-1}$ for samples $h \# 93$ and $h \# 77$, respectively. Three bee honey samples ( $h \# 83, h \# 88$ and $h \# 89$ ) showed no HMF value by the spectrophotometric method, after clarifying samples with Carrez reagents (I and II) and the addition of sodium bisulphate (AOAC, 2000). Only one sample (h\#77) exceeded the allowed legal limits of $60 \mathrm{mg} \mathrm{kg}^{-1}$ (BRASIL, 2000). HMF is regarded as the main degradation product of heated honey obtained from dehydration of hexose in particular at $\mathrm{pH}$ lower than 5 or by the Maillard reaction since HMF content is a suitable feature of honey freshness (TURHAN et al., 2008). Although HMF can be naturally in honey, its content can be increased by the storage conditions, mainly in bee honeys kept at high temperatures. Moreover, the chemical composition (e.g. glucose and fructose contents) performs a remarkable change in the behavior of crystallization which can influence HMF value (CAVIA et al., 2002). Concerning these data, sample $\mathrm{h} \# 77$ can be resulted of overheating, long-time storage or intended addition of commercial sugar products. 
The evaluated bee (A. mellifera) honeys from Campos Gerais region revealed colour between water-white and dark-amber in agreement with the Brazilian legislation (BRASIL, 2000). A total of 63 bee honey samples (67.74\%) were archived as light-amber and extra light-amber. In despite, 12 samples (12.90\%) showed an amber colour. As reported in the literature (NORONHA, 1997), bee honeys with light colours show higher commercial values than dark ones. Also, the colour of bee honeys is a wideranging property because some chemical features as fructose/glucose proportion, instability of fructose in acid medium, nitrogen content and presence of free amino acids, phenolic compounds and ash have a remarkable influence on browning (BATH \& SINGH, 1999).

Kirkwood, Mitchell \& Smith $(1960,1961)$ using a linear discriminant function $\left(X=-8.3 x_{1}-\right.$ $12.3 x_{2}+1.4 x_{3}$ ) in which $x_{1}$ is $p H, x_{2}$ is the honey ash content in percentage and $x_{3}$ is the percentage of reducing sugars, obtained $X=73.1$ for differentiation between floral honey and honeydew or mixed honey. For the evaluated samples, 61 bee honeys (65.59\%) showed $X$ higher than 73.1 and were considered as floral products. Others 32 samples (34.41\%) archived lower values by the Kirkwood equation and were regarded as honeydew or mixed honeys. A. mellifera extracts nectar from flowers to produce floral honeys. However, when bees collect sweet fluids that exude from botanical species usually visited by plant-sucking insects, honeydew honeys are obtained (BRASIL, 2000). Therefore, the Brazilian regulation (BRASIL, 2000) sets that honeydew honeys are legally attested bee product with singular sensorial features and some particular physicochemical parameters. Nevertheless, regarding some traditional confusion over the spelling of honeydew honey ("melato") and commercial sugar products ("melado") in Portuguese, honeydew honeys are often undervalued in the Brazilian market.

\section{CONCLUSION}

In conclusion, most of the samples (76.34\%) of bee (A. mellifera) honeys from Campos Gerais region showed values in accordance with the Brazilian legal requirements for the performed physicochemical parameters. For the non-approved samples (23.66\%), further studies are required to investigate the reasons that can be related to these results in disagreement as diversity of sources, inadequate processing and/or adulterations.

\section{RESUMO}

\section{CONTROLE DA QUALIDADE FÍSICO-QUÍMICA DE MÉIS DE ABELHA DA REGIÃO DOS CAMPOS GERAIS DO PARANÁ - BRASIL}

O mel de abelha (Apis mellifera L.) tem sido amplamente utilizado com finalidades terapêuticas e nutricionais. Análises físico-químicas têm sido extensivamente realizadas para avaliar a produção de mel, assegurando sua autenticidade no que diz respeito aos requisitos legais. O objetivo deste trabalho foi discutir o controle de qualidade de 93 amostras de mel da região dos Campos Gerais do Paraná - Brasil mediante parâmetros físico-químicos. Análises de umidade, açúcares redutores, sacarose, sólidos insolúveis em água, cinzas, acidez livre, $\mathrm{pH}$, atividade diastásica, conteúdo de hidroximetilfurfural e cor foram realizadas por métodos oficiais. As amostras também foram classificadas como mel floral ou mel de melato de acordo com a equação de Kirkwood. No total, 71 amostras (76,34\%) apresentaram valores em conformidade com os requisitos legais brasileiros para todos os parâmetros físico-químicos investigados. Todos os méis atenderam às especificações da legislação apenas para sólidos insolúveis em água e cor. Para o pH, parâmetro adicional não exigido pela legislação para a análise de méis, as amostras apresentaram valores variando de 3,60 a 5,35. Conforme a equação Kirkwood, 61 méis foram considerados como produtos florais.

PALAVRAS-CHAVE: QUALIDADE DO MEL; Apis mellifera L.; ATIVIDADE DIASTÁSICA; ADULTERAÇÕES NO MEL.

\section{REFERENCES}

1 ANKLAM, E. A review of the analytical methods to determine the geographical and botanical origin of honey. Food Chemistry, v. 63, n. 4, p. 549-562, 1998. 
2 AOAC. Association of Official Analytical Chemists. Official methods of analysis of AOAC International. $17^{\text {th }}$ ed. Gaithersburg, MD, 2000. Chapter 44, p. 22-33.

3 BASUALDO, C.; SGROY, V.; FINOLA, M.S.; MARIOLI, J.M. Comparison of the antibacterial activity of honey from different provenance against bacteria usually isolated from skin wounds. Veterinary Microbiology, v. 124, p. 375381, 2007.

4 BATH, P.K.; SINGH, N.A. A comparison between Helianthus annuus and Eucalyptus lanceolatus honey. Food Chemistry, v. 67, n.4, p.389-397, 1999.

5 BIANCHI, E. M. La miel, características y composición: análisis y adulteraciones. Santiago del Estero: UNSE CEDIA, 1981.

6 BOGDANOV, S; GALLMANN, P. Authenticity of honey and other bee products state of the art. Animal Production and Dairy Products (ALP) Science, n. 520, p. 1-12, 2008.

7 BOGDANOV, S.; MARTIN, P.; LÜLLMANN, C. Harminised methods of the European Honey Comission. Apidologie, Paris, Extra Issue, p. 1-59, 1997.

8 BRASIL. Ministério da Agricultura e do Abastecimento. Instrução Normativa n 11, de 20 de outubro de 2000. Regulamento técnico de identidade e qualidade do mel. Available at: <http://extranet.agricultura.gov.br/consultasislegis/ do/consultaLei? op= viewTextual\&codigo=7797>. Accessed in: July 12th, 2009.

9 CAVIA, M.M.; FERNÁNDEZ-MUIÑO, M.A.; GÖMEZ-ALONSO, E.; MONTES-PÉREZ, M.J.; HUIDOBRO, J.F.; SANCHO, M.T. Evolution of frutose and glucose in honey over one year: influence of induced granulation. Food Chemistry, v. 78, p. 157-161, 2002.

10 CODEX ALIMENTARIUS COMISSION. Revised codex standard for honey. Codex Standard, FAO, Roma, 12 - 1981, 2. Ver., 2001. 7 p. Available at: <http://www.codexalimentarius.net/web/standard_list.do?lang=em>. Accessed in: June 21st, 2009.

11 CRANE, E. O livro do mel. São Paulo: Nobel, 1983. 226 p.

12 EMSEN, I.M. A different and safe method of split thickness skin graft fixation: medical honey application. Burns, v. 33, p. 782-787, 2007.

13 FELSNER, M.L.; CANO, C.B.; BRUNS, R.E.; WATANABE, H.M.; ALMEIDA-MURADIN, L.B.; MATOS, J.R. Characterization of monofloral honeys by ash contents trtough a hierarchical design. Journal of Food Composition and Analysis, v. 17, p. 737-747, 2004.

14 KIRKWOOD, K.C.; MITCHELL, T.J.; SMITH, D. Examination of the ocurrence of honeydew in honey. Analyst, v. 85, p. 412-416, 1960.

15 KIRKWOOD, K.C.; MITCHELL, T.J.; SMITH, D. Examination of the ocurrence of honeydew in honey. Part II. Analyst, v. 85 , p. $164-165,1961$.

16 KOMATSU, S.S. Caracterização físico-química de méis de Apis mellifera L. 1758 (Hymenoptera: Apidae) de diferentes municípios do estado de São Paulo. 1996, 90 f. Tese (Doutorado em Ciências) - Escola Superior de Agricultura "Luiz de Queiroz", Universidade de São Paulo, São Paulo, 1996.

17 LUSBY, P.E.; COOMBES, A.L.; WILKINSON, J.M. Bacterial activity of different honeys against pathogenic bacteria. Archives of Medical Research, v. 36, p. 464-467, 2005.

18 MALACALZA, N.H.; MOUTEIRA, M.C; BALDI, M.C.; LUPANO, C.E. Characterisation of honey from different regions of the Province of Buenos Aires, Argentina. Journal of Apicultural Research, v. 46, p. 8-14, 2007.

19 MARCHINI, L.C.; MORETI, A.C. de C.C.; OTSUK, I.P. Análise de agrupamento, com base na composição físico-química, de amostras de méis produzidos por Apis mellifera L. no estado de São Paulo. Ciência e Tecnologia de Alimentos. Campinas, v. 25, n. 1, p. 8-17, 2005.

20 MEDA, A.; LAMINEN, C.E.; MILLOGO, J.; ROMITO, M.; NACOULMA, O.G. Therapeutic uses of honey and honeybee larvae in central Burkina Faso. Journal of Ethnopharmacology, v. 95, p. 103-107, 2004.

21 MEDA, A.; LAMIEN, C.E.; ROMITO, M.; MILLOGO, J.; NACOULMA, O.G. Determination of the total phenolic, flavonoid and proline contents in Burkinia Fasan honey, as well as their radical scaveging activity. Food Chemistry, v. 91, p. 571-577, 2005.

22 MENDES, E.; BROJO PROENÇA, E.; FERREIRA, I.M.P.L.V.O.; FERREIRA, M. A. Quality evaluation of portuguese honey. Carboydrate Polymers, v. 37, p. 219-223, 1998.

23 MERCosUL. Mercado Comum do Sul. Regulamento técnico Mercosul "identidade e qualidade do mel". Resolução GMC No 15/94. Montevidéu, 1999. Available at: <http:/extranet.agricultura.gov.br/consultasislegis/do/ consultaLei?op=viewTextual\&codigo=6020>. Accessed in: July 12th, 2009. 
24 NORONHA, P.R.G. Caracterização de méis cearenses produzidos por abelhas africanizadas: parâmetros químicos, composição botânica e colorimetria. 1997, 147 f. Dissertação (Mestrado em Zootecnia) - Universidade Federal do Ceará, Fortaleza, 1997.

25 PADOVAN G.J.; RODRIGUES L.P.; DE JONG, D.; FAVARO, R.M.D.; YKOSAWA, C.E.; MARCHINI, J.S. Brazilian honey samples evaluated by physical-chemical and carbon isotope ratio analysis. Journal of Apicultural Research, $\mathrm{V}$. 47, p. $87-88,2008$.

26 RODRÍGUEZ, G.O. de; FERRER, B.S. de; FERRER, A.; RODRÍGUEZ, B. Characterization of honey produced in Venezuela. Food Chemistry, v. 84, p. 499-502, 2004.

27 SANTOS, K.S.; MALASPINA, O.; PALMA, M.S. Cinética da diástase em méis de diferentes origens florais. Um novo protocolo experimental. Mensagem Doce, São Paulo, n. 70, p. 2-4, 2003.

28 SILVA, C.L. da; QUEIROZ, A.J. de M.; FIGUEIRÊDO, R.M.F. de. Caracterização físico-química de méis produzidos no Estado do Piauí para diferentes floradas. Revista Brasileira de Engenharia Agrícola e Ambiental, v. 8, n. 2-3, p. 260-265, 2004.

29 SIVAKESAVA, S.; IRUDAYARAJ, J. A rapid spectroscopic technique for determining honey adulteration with corn syrup. Journal of Food Science, v. 66, p. 787-792, 2001.

30 SODRÉ, G. da S.; MARCHINI, L.C.; CARVALHO, C.A.L. Açúcares totais, redutores e sacarose de amostras de Apis mellifera (Hymenoptera: apidae) provenientes da região litoral norte no estado da Bahia. In: SIMPÓSIO LATINO AMERICANO DE CIÊNCIA DE ALIMENTOS, 4, Campinas, 2001. Resumos... Campinas: SBCTA, 2001. p.114.

31 SODRÉ, G. da S.; MARCHINI, L.C.; MORETI, A.C. de C.C.; OTSUK, I.P.; CARVALHO, C.A.L. de. Caracterização físicoquímica de amostras de méis de Apis mellifera L. (Hymenoptera: Apidae) do Estado do Ceará. Ciência Rural, Santa Maria, v.37, n. 4, p. 1139-1144, 2007.

32 TOSI, E.; MARTINET, R.; ORTEGA, M.; LUCERO, H.; RÉ, E. Honey diastase activity modified by heating. Food Chemistry, v. 106, p. $883-887,2008$.

33 TURHAN, I.; TETIK, N.; KARHAN, M.; GUREL, F.; TAVUKCOUGLU, H.R. Quality of honeys influenced by thermal treatment. LWT - Food Science and Technology, v. 41, p. 1396-1399, 2008.

34 VARGAS, T. Caracterização da qualidade do mel produzido nos Campos Gerais. 2006 , $150 \mathrm{f}$. Dissertação (Mestrado em Ciência e Tecnologia de Alimentos) - Universidade Estadual de Ponta Grossa, Ponta Grossa, 2006.

35 WHITE, J.W. Jr. Physical characteristics of honey. In: HONEY: a comprehensive survey. London: Heinemann, 1975, p. 157-206.

\section{ACKNOWLEDGEMENTS}

The authors are grateful to CAPES (Brazil) for the received financial support. 